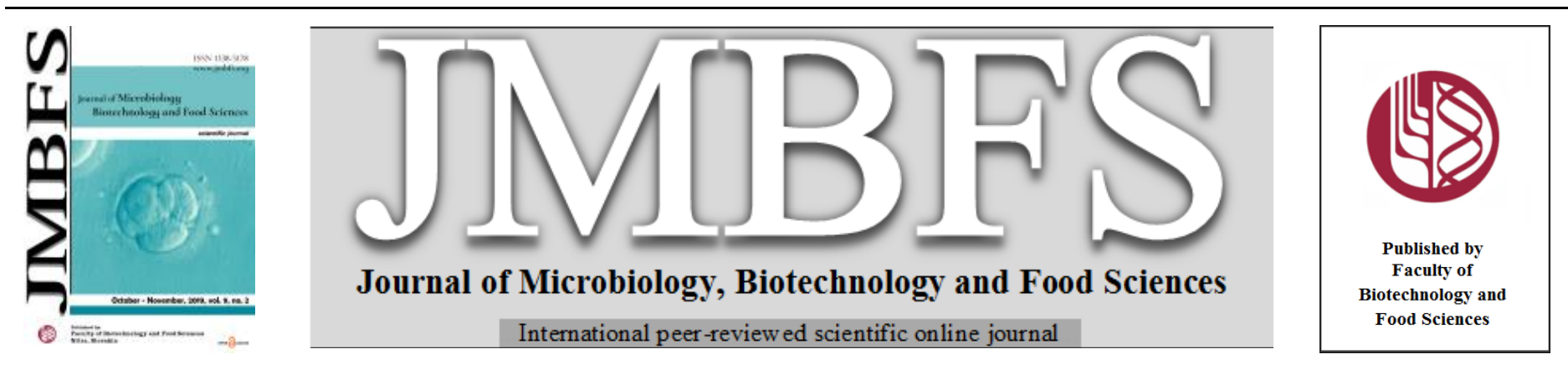

\title{
EVALUATION OF THE FATTY ACID DESATURASE 3 GENES STABILITY IN FLAX SEEDS HARVESTED FROM RADIO-CONTAMINATED AREA NEAR CHERNOBYL
}

\author{
Veronika Lancíková* ${ }^{\text {, Jana Žiarovská }}$ \\ Address(es): \\ ${ }^{1}$ Institute of Plant Genetics and Biotechnology, Plant Science and Biodiversity Center, Slovak Academy of Sciences, Nitra, Slovakia. \\ ${ }^{2}$ Department of Genetics and Plant Breeding, Faculty of Agrobiology and Food Resources, Slovak University of Agriculture, Nitra, Slovakia.
}

*Corresponding author: veronika.lancikova@savba.sk

doi: $10.15414 / j m b f s .2020 .9 .4 .816-819$

\section{ARTICLE INFO}

Received 23. 5. 2019

Revised 16. 9.2019

Accepted 22. 10. 2019

Published 3. 2. 2020

Regular article

OPEN OACCESS

\section{ABSTRACT}

Environment around Chernobyl recoveres from nuclear accident in 1986 and provides a base for plant adaptation research. Here, the initial platform was established for molecular screening of flax genome affected by radioactive contamination. Flax (Linum usitatissimum L.) cultivated in the radio-contaminated, and remediated experimental field near Chernobyl was investigated. Specifically, two gene isoforms of $F A D 3$ gene, $F A D 3 \mathrm{~A}$ and $F A D 3 \mathrm{~B}$, were evaluated using the restriction analysis, and direct sequencing. The aim of the presented study was to identify mutations, and single nucleotide polymorphisms within the FAD3A and FAD3B genes. The investigation was performed more than 25 years after Chernobyl accident. Therefore, the effect of chronic low dose rate irradiation on flax plants was considered.

Keywords: Chernobyl, FAD3A, FAD3B, restriction analysis, direct sequencing

\section{INTRODUCTION}

The accident at Chernobyl Nuclear Power Plant (CNPP) released a total of $7.4 \mathrm{x}$ $10^{16} \mathrm{~Bq}$ of radionuclides into the environment (Moller and Mousseau, 2006). Over the years, the radiological situation in the affected areas was stabilized and the high-dose-rate acute radiation was replaced with persistent low-dose-rate chronic exposure (Geraskin, 2003). It is well known that the exposure of any organism to ionizing radiation is associated with the complex response that include increase in mutation rates, changes in the structure and functionality of the genome (Evans and DeMarini, 1999; Kuchma et al., 2011). Previously it was also well documented that the life in radio-contaminated Chernobyl area is often associated with the increase in mutation rates (Kovalchuk $\boldsymbol{e t}$ al., 2000; Kal'chenko and Fedorov, 2001; Kovalchuk et al., 2003; Vornam et al., 2004; Geras'kin et al., 2005; Møller et al., 2006; Kuchma et al., 2011). Despite that plants grow and successfully reproduce in radio-contaminated Chernobyl area (Klubicova et al., 2013).

Importantly, flax (Linum usitatissimum L.) is the third largest natural fiber crop and one of the five major oil crops in the world (Deng et al., 2011). Oil, extracted from flax seeds, is used as linoleum, varnish, paint, printer's ink, and soap (Cloutier at al., 2009). Moreover, flax oil is increasingly considered as edible oil due to high level of linolenic acid that is generally around $45 \%$ to 65 $\%$ (Damude and Kinney, 2007). Linolenic acid is produced through the desaturation of linoleic acid by omega-3/delta-15 desaturases and in plants, this reaction occurs both in the plastids and in the endoplasmic reticulum (Vrinten $\boldsymbol{e t}$ al., 2005). Flax seed is naturally high in polyunsaturated fatty acids (PUFA) (Jhala, Hall, 2010) and is a rich source of $\alpha$-linolenic acid (ALA), an essential dietary fatty acid of $\omega-3$ class. Desaturases are enzymes that drive the multi-step fatty acid biosynthetic pathway and desaturase genes have been isolated and characterized in several plants, including flax. Membrane bound desaturases, especially delta- 12 and delta- 15 desaturases are currently of considerable interest as targets for manipulation of storage oils in plant seeds (Khadake et al., 2011). In fatty acid biosynthesis pathway the delta-12 fatty acid converts oleic acid $(18: 1)$ to linoleic acid $(18: 2)$ and production of linoleic acid marks the synthesis of polyunsaturated fatty acid (PUFA) from monounsaturated oleic acid. Delta-12 desaturation is also an imperative prerequisite for the synthesis of omega-3 linolenic acid (18:3) (Khadake $\boldsymbol{e t}$ al., 2009) and the delta-15 desaturase ensures the conversion of $\omega-6$ linoleic acid $(18: 2)$ to linolenic acid $(18: 3)$ (Khadake $\boldsymbol{e t}$ al., 2011). This process is the major factor in determining the quality of plant oils (Khadake et al., 2009). Desaturases capable of desaturating linoleic acid are encoded by two independently inherited genes, FAD $3 A$ and FAD $3 B$, in flax. The deduced proteins encoded by these genes share $95.4 \%$ identity (Vrinten et al. 2005).

Molecular marker methods may be defined by the kind of DNA variation or polymorphism they detect and the way in which the polymorphism is detected or visualized. The first DNA-based molecular marker technique was restriction fragment length polymorphism (RFLP) (Schulman et al., 2012). The ease of detection of DNA polymorphisms depends on both frequency and form of sequence variation (Nakitandwe et al., 2007). Analysis of the extent and distribution of genetic diversity in crop plants is essential for optimizing sampling and breeding strategies (Fu et al., 2002).

Chernobyl area is contaminated with long-lived radioisotopes including ${ }^{90} \mathrm{Sr}$ and ${ }^{137}$ Cs (Klubicová et al., 2010) nevertheless, in recent years there has been an increasing tendency toward remediation of contaminated areas for agricultural purposes (Klubicová et al., 2011). The local ecosystem has been able to adapt to a constantly high level of radiation. For the reason to evaluate plant adaptation, seeds of a local flax genotype Kyivskyi were sown in experimental fields of the Chernobyl region (Klubicová et al., 2010). Flax was selected because it is a crop of economic and historical importance, despite the relative paucity of molecular resources (Klubicová et al., 2011). Evaluation of FAD3 gene isoforms was considered because a previous study observed changes in fatty acids composition (unpublished), especially increased alpha-linolenic acid content (data not shown). Two approaches, direct sequencing, and restriction analysis were employed to identify point mutations in FAD3A and FAD3B genes.

\section{MATERIAL AND METHODS}

\section{Experimental fields and biological material}

In 2007, cultivation of flax (Linum usitatissimum L.) of Kyivskyi genotype has began in experimental fields established near Chernobyl. Flax seeds used in this experiment were harvested in 2013, after six consecutive years of growing near Chernobyl. Flax seeds were harvested from radio-contaminated, and remediated experimental field in three biological replicates. Radio-contaminated experimental field is located $5 \mathrm{~km}$ from Chernobyl Nuclear Power Plant (CNPP), near the village Chistogalovka and have soil radioactivity $20650 \pm 1050 \mathrm{~Bq} \cdot \mathrm{kg}^{-1}$ of ${ }^{137} \mathrm{Cs}$, and $5180 \pm 550 \mathrm{~Bq} \cdot \mathrm{kg}^{-1}$ of ${ }^{90} \mathrm{Sr}$. Remediated field is located directly in Chernobyl town and have soil radioactivity $1414 \pm 71 \mathrm{~Bq} \cdot \mathrm{kg}^{-1}$ of ${ }^{137} \mathrm{Cs}$ and $550 \pm$ $55 \mathrm{~Bq} \cdot \mathrm{kg}^{-1}$. Contents of aleurite (silt) and pelitic soil ranges from 20 to $30 \%$ in both experimental fields. The soils contain $12 \%$ 
clay, $2 \%$ organic material, and are sod-podzolic with a loamy-sand texture, which is derived from sandy fluvio-glacial deposits. Soil in remediated field has $\mathrm{pH}$ of 6.6 , and in radio-contaminated field $\mathrm{pH}$ of 5.6. The electric conductivity of soils in both fields is $0.20 \mathrm{dS} . \mathrm{m}^{-1}$.

\section{DNA isolation}

Genomic DNA was isolated using the method described by Rogers and Bendich (1994). In total $0.5 \mathrm{~g}$ (approximately 100 seeds) of mature flax seeds were ground to a fine powder with a mortar and pestle in liquid nitrogen. The powder was suspended in extraction solution $(50 \%(\mathrm{v} / \mathrm{v})$ phenol, $0.45 \mathrm{M}$ sucrose, $5 \mathrm{mM}$ EDTA, $0.2 \%(\mathrm{v} / \mathrm{v})$ 2-mercaptoethanol, $50 \mathrm{mM}$ Tris-HCL, $\mathrm{pH} 8.8$ ) and shaken for $30 \mathrm{~min}$ at $4{ }^{\circ} \mathrm{C}$. After the centrifugation at $5000 \mathrm{~g}$ for $10 \mathrm{~min}$ at $4{ }^{\circ} \mathrm{C}$, the aquatic phase was transferred into new tube. The one volume of phenol-chloroformisoamylalcohol solution (25:24:1) was added to aquatic phase, and mixed vigorously, then centrifuged at $9500 \mathrm{~g}$ for $15 \mathrm{~min}$ at $4{ }^{\circ} \mathrm{C}$. Phenol-chloroform extraction was repeated until clear aquatic phase without brown blur. DNA precipitation was carried out with one volume of isopropanol, incubation for 20 min at room temperature, and centrifugation at $5000 \mathrm{~g}$ for $5 \mathrm{~min}$ and subsequent washing with one volume of $70 \%$ ethanol. Nucleic acid precipitate was transfe to new tube and dissolved in $300 \mu 1$ TE buffer (pH 8, 10 mMTris, 1mM EDTA)

\section{Restriction analysis}

The restriction analysis of FAD3A (HM991828.1) and FAD3B (HM991832.1) genes was performed. The promoter, and coding regions of FAD $3 \mathrm{~A}$, and FAD3B were amplified for further restriction digestion. Primers were designed using the NCBI primer designing tool (National Center for Biotechnology Information, Bethesda, USA). The primer sequences are shown in table 1. PCR reactions mixture contained Termo Scientific Dream Taq PCR Master Mix (2×); Dream Taq DNA polymerase is supplied in $2 \times$ Dream Taq buffer; dATP, dCTP, dGTP and dTTP $\left(0,4\right.$ mmol.dm ${ }^{-3}$ each $) ; 4$ mmol. $\mathrm{dm}^{-3} \mathrm{MgCl}_{2}$ and $400 \mathrm{nmol} . \mathrm{dm}^{-3}$ of each primer (table 1). Amplification was performed in $\mathrm{C} 1000$ Thermal Cycler under following conditions: $94{ }^{\circ} \mathrm{C} 4 \mathrm{~min} ; 94{ }^{\circ} \mathrm{C} 45 \mathrm{sec}, 61{ }^{\circ} \mathrm{C} 30 \mathrm{sec}, 72{ }^{\circ} \mathrm{C} 2 \mathrm{~min} ; 72$ ${ }^{\circ} \mathrm{C} 10 \mathrm{~min}$. PCR products were verified on $1 \%$ agarose gel.

Table 1 Nucleotide sequences of primers applied for PCR amplification of $F A D 3 \mathrm{~A}$ and $F A D 3 \mathrm{~B}$ genes in flax

\begin{tabular}{|c|c|c|c|}
\hline Gene & & Primer sequence 5'-3' & $\begin{array}{l}\text { PCR product } \\
\text { (bp) }\end{array}$ \\
\hline \multirow[t]{14}{*}{$A D 3 \mathrm{~A}$} & 1_For & ATCGCCACAACTTCGAACCA & 1179 \\
\hline & 1_Rev & AATGCAGGATGCCAAGTGGA & \\
\hline & 2_For & ATCCCTCTGCCCGAAACTTG & 754 \\
\hline & 2_Rev & ATCTTGAAAGGGGGAGCAGC & \\
\hline & 3_For & GAAGAACCTAGCAGCCAGCA & 765 \\
\hline & 3_Rev & TGCATGCAACAGCCCAGATA & \\
\hline & 4_For & CTGGACAGCTGGACTGTCTG & 933 \\
\hline & 4_Rev & GCTGCCCAATTCCGTTTTGT & \\
\hline & 5_For & GCCACTCAGTCTATTCATTA & 1201 \\
\hline & 5_Rev & CTAGAATTGAGGAAAAAACATG & \\
\hline & 6_For & ATCTGGCGATGGGTGTGCGG & 1500 \\
\hline & 6_Rev & CAAGAAGGAAATCCCCTGACTCC & \\
\hline & 7_For & TGACGGGTGTCGTGGATGGAT & 1924 \\
\hline & 7_Rev & ATGACAATGGAACCAGAGAGC & \\
\hline \multirow[t]{10}{*}{ FAD3B } & 1_For & AAGACCGATGCCCACTTGAG & 1992 \\
\hline & 1_Rev & AGCGTGCAGCACCTAATCTT & \\
\hline & 2_For & ATACTGTGAGCCTCAAAGCA & 1244 \\
\hline & 2_Rev & GACAGAATTACCCAATGTCAG & \\
\hline & 3_For & GTAAGTAAAGAGACTGATAAG & 1330 \\
\hline & 3_Rev & ATTGACCAGGGATCGGATTT & \\
\hline & 4_For & CGATTTCGGCGGAATTGGAC & 1789 \\
\hline & 4_Rev & ACTGCTGGTACGGAACTTGG & \\
\hline & 5_For & AGCGGTAAACAATTTGATTAT & 1279 \\
\hline & 5_Rev & AACACAGTCGAAACCCTATA & \\
\hline
\end{tabular}

For restriction analysis, ten microliters of PCR product was digested with $0.5-5$ $\mathrm{U}$ of the appropriate enzyme in a total volume of $30 \mu \mathrm{l}$ for 3 hours. Digests were evaluated on $1.5 \%$ agarose gels. Electrophoresis was conducted at a voltage of $60 \mathrm{~V}$ for $2 \mathrm{~h}$. Electrophoreograms were processed with documentation system $\mathrm{G}$ : Box in GeneSnap program - Product version: 7.09 (Syngene). Restriction endonucleases employed for FAD3 genes analysis, and their recognized restriction sites are shown in table 2. Restriction enzymes for the study were selected according the software NEBcutter V2.0 (Vincze $\boldsymbol{e t}$ al., 2003). Selected enzymes were identified as the restriction endonucleases with the highest coverage of cutting sites within analysed genes.

Table 2 Characterization of restriction endonucleases selected for restriction analysis of $F A D 3 \mathrm{~A}$ and $F A D 3 \mathrm{~B}$ genes

\begin{tabular}{|c|c|c|c|}
\hline Gene & $\begin{array}{l}\text { Restriction } \\
\text { endonuclease }\end{array}$ & $\begin{array}{l}\text { Recognized } \\
\text { restriction site }\end{array}$ & $\begin{array}{l}\text { No. of cutting } \\
\text { sites }\end{array}$ \\
\hline \multirow[t]{5}{*}{ FAD3A } & MnlI & $\mathrm{CCTC}(\mathrm{N})_{6} \iota \mathrm{N}$ & 32 \\
\hline & NlaIII & CATG & 33 \\
\hline & AciI & $\mathrm{C}$ CGC & 16 \\
\hline & AluI & $\mathrm{AG} \mathrm{CT}$ & 25 \\
\hline & ScrFI & $\mathrm{CC} \mathrm{NGG}$ & 12 \\
\hline \multirow[t]{6}{*}{$F A D 3 B$} & $M n l \mathrm{I}$ & $\mathrm{CCTC}(\mathrm{N})_{6} \wedge \mathrm{N}$ & 27 \\
\hline & AciI & $\mathrm{C} \mathrm{CG}_{\star} \mathrm{C}$ & 20 \\
\hline & NlaIII & CATG & 26 \\
\hline & $B s a \mathrm{JI}$ & $\mathrm{C} . \mathrm{CNNGG}$ & 11 \\
\hline & FatI & CATG & 26 \\
\hline & Hpy188I & $\mathrm{TC} \_\mathrm{N}$ GA & 23 \\
\hline
\end{tabular}

\section{Direct sequencing}

Direct sequencing of $F A D 3 \mathrm{~A}$, and FAD3B PCR products was performed. PCR products were purified using QIAquick PCR purification kit (Qiagen, Venlo, Netherlands), and commercially sequenced. Microsynth AG, Austria provided sequencing services. The raw chromatograms were processed using Chromas Lite 2.6.6 software (Technelysium Pty Ltd., South Brisbane, QLD, and Australia). Nucleotide sequences of $F A D 3 \mathrm{~A}$, and $F A D 3 \mathrm{~B}$ genes in flax seeds cultivated in radio-contaminated, and remediated fields were compared against original sequences from NCBI database to identify the presence of mutations. For $\begin{array}{lllll}\text { evaluation of nucleotide } & \text { sequences } & \text { ClustalX } & \end{array}$ (http://www.clustal.org/clustal2/) software was used.

\section{RESULTS AND DISCUSSION}

Herein, the flax seeds harvested from radio-contaminated, and remediated fields near Chernobyl with certain level of radioactive contamination were analysed. Previously obtained data (unpublished) indicates the increasing in alpha-linolenic acid content in flax seeds cultivated on the radio-contaminated experimental field. Therefore, two essential isoforms of $F A D 3$ gene responsible for the conversion of linoleic acid to alpha-linolenic acid, FAD3A and FAD3B, were evaluated. Combination of restriction analysis to screen specific cleavage sites and direct sequencing of PCR products was applied. The major aim of the study was to identify point mutations caused by irradiation stress in the Chernobyl environment. The FAD3A gene was digested using the following enzymes $\mathrm{Mnl \textrm {I }}$, NlaIII, AciI, AluI, ScrFI, and the FAD3B using the MnlI, AciI, NlaIII, BsaJI, FatI, and Hpy $188 \mathrm{I}$ restriction endonucleases. Restriction profiles obtained by analysis were aligned against restriction sites virtually predicted by NebCutter V2.0 (Vincze et al. 2003). The analysis resulted in the monomorphic restriction profiles in both investigated genes. The polymorphism was not detected between flax seeds harvested from radio-contaminated, and remediated experimental field near Chernobyl.

In order to confirm the absence of mutations, and single nucleotide polymorphisms (SNPs) in sequences of $F A D 3 \mathrm{~A}$, and $F A D 3 \mathrm{~B}$, direct sequencing of PCR products was employed. Sequencing results were in agreement with restriction analysis, and no changes were found at the nucleotide level of analysed $F A D 3$ genes. 


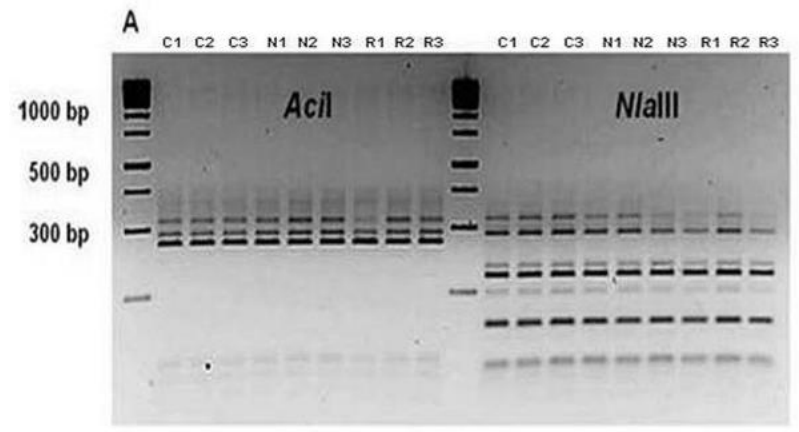

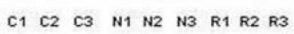

$\begin{array}{lllllllll}C 1 & C 2 & C 3 & N 1 & N 2 & N 3 & R 1 & R 2 & R 3\end{array}$

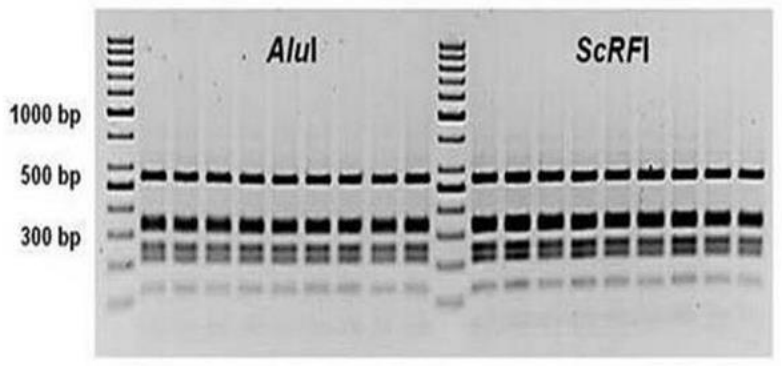

B
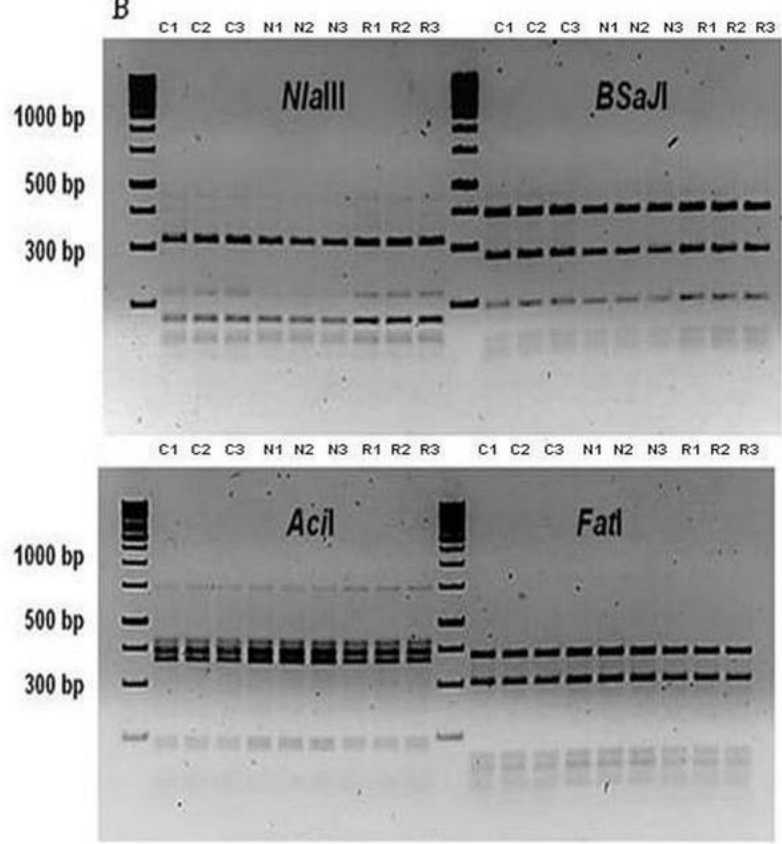

Fig.1 Fragments of restriction patterns determined for two FAD3 gene isoforms; three groups of flax seeds were analysed in biological triplicate, group 1 are flax seeds used to establish experimental fields in 2007 with no previous contact with Chernobyl environment, these seeds were used as controls (restriction profiles are labeled as $\mathrm{C} 1, \mathrm{C} 2, \mathrm{C} 3$ ); group 2 are flax seeds harvested from nonradioactive (remediated) experimental field (N1, N2, N3); group 3 are flax seeds harvested from radiocontaminated experimental field near Chernobyl (R1, R2, R3); A shows restriction profiles of FAD3A gene using the AciI, NlaIII, AluI, and ScRFI enzymes; B shows restriction profiles of FAD3B gene using the NlaIII, BSaJI, AciI, and FatI enzymes.

Currently, no genomic data are available for common flax affected by long-term chronic exposure to radiation. While the area in near proximity to the Chernobyl still remains substantially contaminated with long-lived radioisotopes such as ${ }^{90} \mathrm{Sr}$ and ${ }^{137} \mathrm{Cs}$, local ecosystems are reportedly adapted to radio-contamination (Vornam et al., 2004; Klubicová et al., 2010; Abramov et al., 2011). The following defence mechanisms allows plants to survive under the harsh environmental conditions a) ability to repair DNA damage after the low-dose irradiation (Abramov et al., 2011), b) stimulated repopulation, i.e the replacement of damaged cells with undamaged (Serebryanyi and Zoz, 2002), c) activation of plants antioxidant system (Abramov et al., 2011), d) epigenetic changes manifested through the genome hypermethylation (Kovalchuk $\boldsymbol{e t}$ al., 2003).

Flax is a promising candidate for investigation of molecular alterations because of a high level of genetic diversity and active genomic responses to abiotic stress (Cloutier et al., 2012). The effects of ionizing radiation on genetic material of higher plants, and its involvement in both adaptive processes and species evolution was investigated by Esnault $\boldsymbol{e t}$ al. (2010). Chronic, and long-term irradiation may affect the genetic structure of populations, and genetic variability might be reduced. The effect of long-term chronic exposure to radionuclides was discussed in the study presented by Geras'kin et al. (2013). Ionizing radiation causes primary damage at the molecular level, however plants are able to increase a resistance of population to exposure under the long-term radioactive contamination. This may explain the stability of investigated $F A D 3$ genes. Plants may respond to the chronic low-dose radiation stress differently than to the acute high-dose radiation. Chronic low-dose irradiation may lead to the adjustment of adaptation mechanisms. Hence, plant can be able to cope with environmental radiation stress with only minor genomic rearrangements.

\section{CONCLUSION}

In conclusion, flax of local ukrainian genotype Kyivskyi cultivated in the experimental fields near Chernobyl was investigated at the molecular level Specifically, two gene isoforms, $F A D 3 \mathrm{~A}$ and $F A D 3 \mathrm{~B}$, essential for synthesis of alpha-linolenic acid were evaluated. The presence of mutations, and SNPs in genomic DNA of $F A D 3$ genes was investigated using the restriction analysis, and direct sequencing. Polymorphism was not revealed between flax seeds harvested from radio-contaminated, and remediated field. It can be concluded that exposure to the ionizing radiation has no significant effect on the stability of FAD $\mathrm{A}$ and FAD3B genes.

Acknowledgments: This work was co-funded by a grant from the Slovak Grant Agency VEGA 2/0075/17 and Research Centre AgroBioTech built in the framework of European Community project Building Research Centre "AgroBioTech" ITMS 26220220180. The authors thank to Dr. Martin Hajduch for project coordination, prof. Namik M Rashydov for coordination of experimental fields and sample collection, Mrs. Valentyna V. Berezhna and Mr. Volodymyr Sakada for technical help with maintenance of the Chernobyl fields.

\section{REFERENCES}

ABRAMOV, V.I., STEPANOVA, A.A., FAMELIS, S.A. (2011). Some radiobiological effects in higher plants growing on

the territory of the East Ural Radioactive Trace. Biophysics, 56,129-143.

CLOUTIER, S., MIRANDA, E., WARD, K., RADOVANOVIC, N., REIMER, E., WALICHNOWSKI, A., DATLA, R., ROWLAND, G., DUGUID, S. RAGUPATHY, R. (2012). Simple sequence repeat marker development from bacterial artificial chromosome end sequences and expressed sequence tags of flax (Linum usitatissimum L.). Theoretical and Applied Genetics, 125(4), 685694. https://dx.doi.org/10.1007/s00122-012-1860-4

DENG, X., LONG, S., HE, D., LI, X., WANG, Y., HAO, D., QIU, C., CHEN, X (2011). Isolation and characterization of polymorphic microsatellite markers from flax (Linum usitatissimum L.). African Journal of Biotechnology, 10(5), 734-739.

ESNAULT, M., LEGUE, F., CHENAL, C. (2010). Ionizing radiation: Advances in plant response. Environmental and Experimental Botany, 68, 231-237. https://dx.doi.org/10.1016/j.envexpbot.2010.01.007

FU, B.Y., DIEDERICHSEN, A., RICHARDS, K.W., PETERSON, G. (2002) Genetic diversity within a range of cultivars and landraces of flax (Linum usitatissimum L.) as revealed by RAPDs. Genetic Resources and Crop Evolution, 49(2), 167-174. https://dx.doi.org/10.1023/A:10147160

GERAS'KIN, S., EVSEEVA, T., OUDALOVA, A. (2013). Effects of long-term chronic exposure to radionuclides in plant populations. Journal of Environmental Radioactivity, 121, 22-32. https://dx.doi.org/10.1016/j.jenvrad.2012.03.007

JHALA, J.A., HALL, M.L. (2010). Flax (Linum usitatissimum L.): Current Uses and Future Applications. Australian Journal of basic and Applied Sciences, 4(9), 4304-4312.

KHADAKE, R., KHONDE, V., MHASKE, V., RANJEKAR, P., HARSULKAR, A. (2011). Functional and bioinformatic characterisation of sequence variants of Fad3 gene from flax. Journal of the Science of Food and Agriculture, 91, 26892696. https://dx.doi.org/10.1002/jsfa.4515

KHADAKE, R., RANJEKAR, P., HARSULKAR, A. (2009). Cloning of a Novel Omega-6 Desaturase from Flax (Linum usitatissimum L.) and Its Functional Analysis in Saccharomyces cerevisiae. Molecular Biotechnology, 42, 168-174 https://dx.doi.org/10.1007/s12033-009-9150-3

KLUBICOVÁ, K., BERČÁK, M., DANCHENKO, M., SKULTETY, L. RASHYDOV, N.M., BEREZHNA, V.V., MIERNYK, J.A., HAJDUCH, M (2011). Agricultural recovery of a formerly radioactive area: I. Establishment of high-resolution quantitative protein map of mature flax seeds harvested from the remediated Chernobyl area. Phytochemistry, 72(10), 1308-1315. https://dx.doi.org/ 10.1016/j.phytochem.2010.11.010

KLUBICOVÁ, K., DANCHENKO, M., SKULTETY, L., MIERNYK, A.J., RASHYDOV, N.M., BEREZHNA, V.V., PREŤOVÁ, A., HAJDUCH, M. 2010 
Proteomics Analysis of Flax Grown in Chernobyl Area Suggests Limited Effect of Contaminated Environment on Seed Proteome. Environmental Science and Technology, 44(18), 6940-6946. https://dx.doi.org/10.1021/es100895s

NAKITANDWE, J., TROGNITZ, F., TROGNITZ, B. (2007). Reliable allele detection using SNP-based PCR primers containing Locked Nucleic Acid: application in genetic mapping. Plant Methods, 3(2). https://dx.doi.org/10.1186/1746-4811-3-2

OH, J.T., GORMAN, M., CULLIS, A.C. (2000). RFLP and RAPD mapping in flax (Linum usitatissimum). Theoretical and Applied Genetics, 101, 590-593. https://dx.doi.org/10.1007/s001220051520

ROGERS, S., BENDICH, A. (1994). Extraction of total cellular DNA from plants, algae and fungi. Plant molecular biology manual, 8(1). https://dx.doi.org/10.1007/978-94-011-0511-8_12

SCHULMAN, H.A., FLAVEL, J.A., PAUX, E., ELLIS, N. (2012). The Application of LTR Retrotransposons as Molecular Markers in Plants. Methods in Molecular Biology, 859, 115-153. https://dx.doi.org/10.1007/978-1-61779. 603-6 7

SEREBRYANYI, A.M., ZOZ, N.N. (2002). Stimulated Repopulation as a Basis of Antimutagenesis and the Adaptive Response in Plants. Genetics, 38, 264-268.

VINCZE, T., POSFAI, J., ROBERTS, R.J. (2003). NEBcutter: a program to cleave DNA with restriction enzymes.

Nucleic Acids Res, 31, 3688-3691. https://dx.doi.org/10.1093/nar/gkg526

VORNAM, B., KUCHMA, O., KUCHMA, N., ARKHIPOV, A., FINKELDEY, R. (2004). SSR markers as tools to reveal

mutation events in Scots pine (Pinus sylvestris L.) from Chernobyl. Eur. J. Forest Res, 123, 245-248.

https://dx.doi.org/10.1007/s103420040026-6

VRINTEN, P., HU, Z., MUNCHINSKY, A.M., ROWLAND, G., QIU, X.

(2005). Two FAD3 Desaturase Genes Control the Level of Linolenic Acid in

$\begin{array}{llll}\text { Flax Seed. Plant Physiology, 139(1), 79-87. } & \text {. }\end{array}$

http://dx.doi.org/10.1104/pp.105.064451 